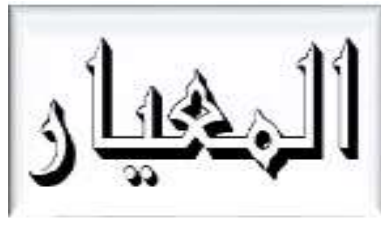

Al Mi'yar

Vol. 2, No. 2, Oktober 2019

P-ISSN: 2620-6749, E-ISSN: 2620-6536

DOI: $10.35931 / a m . v 2 \mathrm{i} 2.141$

\title{
PENERAPAN HASIL MODIFIKASI PERMAINAN MONOPOLI SEBAGAI MEDIA PEMBELAJARAN BERBICARA BAHASA ARAB
}

\author{
Silfiyah Rohmawati \\ Institut Agama Islam Negeri (IAIN) Jember \\ Email: silfiyahrohmawatiali@gmail.com
}

\begin{abstract}
This study is purposed to describe the result application of monopoly game modification as a learning media of Arabic speaking in Program for Arabic Language Development (PKPBA) of the State Islamic University (UIN) of Maulana Malik Ibrahim Malang. This study uses a qualitative approach with descriptive research type. The data collection techniques used are participant observation and documentation. The results of this study are in the form of steps taken by the researcher in applying result modification of monopoly game as a learning media of Arabic speaking. The activities of the game include expressing thoughts, ideas, feelings, experiences and information through telling stories and asking questions about the materials mentioned.

As for the recommendations, the results of the modification of the monopoly game in this study can be applied in learning to speak Arabic, but can also be used for other language competencies, such as listening, reading and writing, and certainly with several different and adaptable game rules. The results of this study can be used as a material modification of the monopoly game that will be used by tutors or other lecturers by adjusting the material and the ability level of students.
\end{abstract}

Keyword: Modifikasi, Permainan Monopoli, Media Pembelajaran, Berbicara Bahasa Arab.

\section{PENDAHULUAN}

Salah satu keterampilan yang harus dikuasai oleh pembelajar bahasa, khususnya bahasa Arab, yaitu berbicara. Dengan berbicara, seseorang dapat menyampaikan gagasan, ide, pemikiran, perasaan dan keinginan. Hal itu 
Silfiyah Rohmawati: Penerapan Hasil Modifikasi Permainan Monopoli Sebagai Media Pembelajaran Berbicara Bahasa Arab

sebagaimana disampaikan oleh Ahmad Fuad Mahmud ${ }^{1}$ bahwa berbicara adalah keterampilan bahasa aktif, karena pembelajar dituntut untuk mengekspresikan dan mengungkapkan perasaan, pemikiran, pendapat, infomasi dan lain sebagainya dengan lancar dan benar Begitu juga, dengan berbicara, seseorang dapat melakukan komunikasi dengan orang lain. Dengan demikian, berbicara memiliki banyak manfaat yang diperoleh.

Aktifitas berbicara tidak bisa terpisah juga dengan kompetensi mendengar. Karena suatu komunikasi akan terjalin dengan baik, jika pembicara bisa memahamkan pendengar dan pendengar juga bisa memahami apa yang dikatakan oleh pembicara. Maka dalam proses pembelajaran berbicara bahasa Arab, sebaiknya guru memberikan banyak latihan aktivitas berbicara yang bertujuan untuk komunikasi aktif.

Dalam proses pembelajaran berbicara bahasa Arab, seringkali guru atau tutor menemukan beberapa masalah yang menjadikan kegiatan belajar menjadi pasif, membosankan dan tidak menarik. Masalah tersebut bisa muncul dari guru itu sendiri, seperti kurangnya persiapan dalam mengajar atau dari pembelajar, seperti muncul rasa malu, minim motivasi, kurang penguasaan kosa kata dan lain sebagainya.

Berdasarkan observasi yang dilakukan oleh peneliti saat mengajar di Program Khusus Pengembangan Bahasa Arab (PKPBA) di Universitas Islam Negeri (UIN) Maliki Malang, terutama di kelas menengah dan kebawah, ditemukan banyak mahasiswa yang merasa kesulitan jika disuruh untuk berbicara bahasa arab, mereka juga mengakui telah merasakan kesulitan itu.

Kesulitan-kesulitan yang dialami oleh mahasiswa tersebut, diantaranya adalah rasa takut yang dialami mahasiswa saat berbicara, mereka takut jika terjadi kesalahan dalam segi kaidah nahwu dan shorof dan minimnya kosakata mereka, jadi sebenarnya banyak yang ingin mereka ungkapkan,

${ }^{1}$ Ahmad Fuad Mahmud. Al-Mahaaraat Al-Lughowiyyah Maahiyatuha Wa Tharaaiqu Tadriisiha. (Riyad: Daarul Muslim:1992). h, 86. 
Silfiyah Rohmawati: Penerapan Hasil Modifikasi Permainan Monopoli Sebagai Media Pembelajaran Berbicara Bahasa Arab

namun mereka tidak mengetahui kosakata bahasa Arab-nya. Hal demikian yang bisa menyebabkan mereka malu dalam berbicara.

Pada hakikatnya, dalam pembelajaran kompetensi berbicara, guru tidak perlu banyak berbicara, sebaiknya berbicara secukupnya dan memberikan banyak kesempatan kepada siswa untuk berbicara, sebab kemampuan berbicara itu merupakan salah satu kompetensi bahasa yang membutuhkan pembiasaan, semakin siswa sering berbicara, maka akan lebih lancar berbicara.

Guru sebenarnya yang menjadi kunci keberhasilan dalam pembelajaran bicara. Kemacetan dalam proses pembelajaran tidak akan terjadi, jika guru dapat secara tepat memilih topik pembicaraan sesuai dengan tingkat kompetensi siswa, dan memiliki kreativitas dalam mengembangkan modelmodel pengajaran berbicara yang banyak sekali variasinya. ${ }^{2}$

Untuk mengatasi hambatan-hambatan sebagaimana yang telah dijelaskan diatas, guru bisa menggunakan atau mengembangkan metode, strategi atau media yang akan digunakan untuk proses pembelajaran berbicara bahasa Arab. Hal demikian bertujuan untuk menarik minat dan memotivasi siswa untuk berbicara bahasa Arab dengan maksimal.

Diantara solusi untuk mengatasi hambatan-hambatan dalam pembelajaran berbicara bahasa Arab adalah penggunaan media yang merupakan salah satu faktor yang mendukung lancarnya proses pembelajaran. Dengan media, guru bisa menarik minat belajar siswa dan menjadikan proses pembelajaran menjadi menyenangkan, sehingga siswa tidak mudah merasakan bosan dan bisa antusias dalam belajar.

Media pembelajaran bisa berupa permainan. Diantaranya adalah permainan monopoli yang merupakan salah satu permainan papan yang h,150.

2 Ahmad Fuad Effendy. Metodologi Pengajaran Bahasa Arab. (Malang: Misykat, 2011). 
Silfiyah Rohmawati: Penerapan Hasil Modifikasi Permainan Monopoli Sebagai Media Pembelajaran Berbicara Bahasa Arab

terkenal di dunia. Permainan ini mudah digunakan, karena sering dimainkan oleh anak-anak untuk hiburan di waktu senggangnya, namun ada beberapa juga yang kurang familiar karena tidak pernah memainkannya. Permainan monopoli bisa dimodifikasi dan dimanfaatkan dalam proses pembelajaran berbicara bahasa Arab.

Dalam hal ini, peneliti akan menerapkan hasil modifikasi permainan monopoli dalam pembelajaran berbicara bahasa Arab di kelas B5 Putri tahun 2016. Kelas tersebut merupakan dalam kategori kelas yang memiliki kemampuan menengah. Dan tujuan diterapkannya permaianan ini adalah untuk membiasakan mahasiswa dalam berbicara bahasa Arab dengan baik dan lancar.

Ada beberapa penelitian sejenis yang sudah pernah dilakukan. Diantaranya adalah penelitian yang dilakukan oleh Purwanto, Ika Mustikasari dan Hanna Nurul Husna tentang Implementasi Permainan Monopoli Fisika sebagai Media Pembelajaran dalam Pembelajaran Kooperatif Tipe TGT untuk Meningkatkan Prestasi Belajar dan Mengetahui Profil Kemampuan Berpikir Kritis Siswa SMP. Hasil dari penelitian tersebut secara umum yaitu , siswa memberikan respon yang positif terhadap penggunaan permainan Monopoli Fisika sebagai Media Pembelajaran. ${ }^{3}$ Dan penelitian yang dilakukan oleh Maya Siskawati, Pargito, Pujiati tentang Pengembangan Media Pembelajaran Monopoli untuk Meningkatkan Minat Belajar Geografi Siswa. Hasil penelitian dan pengembangan ini menunjukkan bahwa validasi ahli menyatakan produk menarik dan layak untuk digunakan sebagai media pembelajaran Geografi,

3 Purwanto, Ika Mustika Sari dan Hanna Nurul Husna. 2012. Implementasi Permainan Monopoli Fisika sebagai Media Pembelajaran dalam Pembelajaran Kooperatif Tipe TGT untuk Meningkatkan Prestasi Belajar dan Mengetahui Profil Kemampuan Berpikir Kritis Siswa SMP. Jurnal Pengajaran Matematika dan Ilmu Pengetahuan Alam. 17 (1). h, 69. 
Silfiyah Rohmawati: Penerapan Hasil Modifikasi Permainan Monopoli Sebagai Media Pembelajaran Berbicara Bahasa Arab

dan pembelajaran dengan menggunakan media monopoli efektif untuk meningkatkan minat belajar Geografi siswa. ${ }^{4}$

Dari penelitian-penelitian diatas, diperoleh keterangan bahwa monopoli dapat digunakan sebagai media pembelajaran, baik bahasa maupun non bahasa. Dalam penelitian ini, peneliti akan mendiskripsikan penerapan hasil modifikasi permainan monopoli serta proses dan langkah-langkah yang dilakukan dalam penerapannya sebagai media pembelajaran berbicara bahasa Arab pada tingkat perguruan tinggi.

\section{Modifikasi Permainan Monopoli}

Modifikasi menurut Kamus Besar Bahasa Indonesia (KBBI) yaitu Pengubahan. Kata modifikasi dapat digunakan untuk sesuatu yang kongkrit maupun abstrak. Contoh dari penggunaan modifikasi kongkrit yaitu modifikasi sepeda, mobil, computer dan lain-lain. Adapun contoh penggunaan modifikasi untuk abstrak yaitu modifikasi perilaku dan pemikiran. Modifikasi juga bisa digunakan dalam dunia Pendidikan, misalnya modifikasi kurikulum, metode pembelajaran, media pembelajaran, dan lain-lain.

Terkait pengertian modifikasi, Bahagia mengemukakan bahwa modifikasi dapat diartikan sebagai upaya melakukan perubahan dengan penyesuaian-penyesuaian baik dalam segi fisik material yang berupa fasilitas dan perlengkapan, maupun dalam tujuan dan cara yang berupa metoda, gaya, pendekatan, aturan serta penilaian. dari pernyataan diatas mengenai pengertian modifikasi, modifikasi merupakan suatu usaha perubahan yang dilakukan berupa penyesuaian-penyesuaian baik dalam bentuk fasilitas dan perlengkapan atau dalam metoda, gaya, pendekatan, aturan serta penilaian. ${ }^{5}$

4 Siskawati, Maya, Pargito dan Pujiati. 2016. Pengembangan Media Pembelajaran Monopoli untuk Meningkatkan Minat Belajar Geografi Siswa. Jurnal studi sosial. 4 (1). h, 72.

5 Bahagia, suherman. 2000. Prinsip-prinsip pengembangan dan Modifikasi cabang olahraga. Jakarta: Departemen pendidikan dan kebudayaan direktorat jenderal pendidikan dasar dan menengah bagian proyek penataran guru SLTP Setara D-III dalam M. Wanda Aginta 
Silfiyah Rohmawati: Penerapan Hasil Modifikasi Permainan Monopoli Sebagai Media Pembelajaran Berbicara Bahasa Arab

Dari definisi bahagia diatas, modifikasi bisa dipraktekkan dalam salah satu perangkat pembelajaran yaitu media pembelajaran, dalam hal ini pembelajaran berbicara bahasa Arab. Media tersebut dapat berupa media audio, visual, ataupun audiovisual.

Permainan dapat digunakan sebagai media dalam pembelajaran bahasa Arab. Dengan permainan, seorang pendidik dapat menjadikan proses pembelajaran tersebut menjadi menyenangkan dengan tujuan agak peserta didik mampu mencapai tujuan dari pembelajaran dengan rasa senang.

Permainan bahasa memiliki peran penting dalam pembelajaran. Permainan bahasa bisa menarik dan menjaga motivasi peserta didik dalam proses pembelajaran. Menurut Tsair Ahmad Ghibari, diantara manfaat permainan dalam pembelajaran adalah membantu peserta didik untuk berinteraksi dengan lingkungan, membantu perserta didik untuk mengembangkan diri, sebagai media untuk memperoleh pola sikap yang berbeda, sebagai media untuk mengembangkan pola sikap, dan permainan motorik yang dilakukan peserta didik bisa membantu untuk persiapan mengembangkan kemampuan kognitif yang berkelanjutan. ${ }^{6}$

Permainan dalam pembelajaran Bahasa memiliki beberapa fungsi. Pertama, menjadikan proses belajar mengajar menjadi kegiatan yang menyenangkan. Kedua, memberikan stimulus kepada guru dan siswa supaya pembelajaran menjadi menyenangkan. Ketiga, melatih unsur-unsur bahasa dan pengembangan keterampilan bahasa yang berbeda. ${ }^{7}$

Bangun. 2018. Pemanfaatan Hasil Modifikasi Pembelajaran Pendidikan Jasmani di SLB-YPAC Cabang Medan. Physical Education, Healt and Recreation. 2 (2). h.100.

6 Tsair Ahmad Ghibari. Ad Dafi'iyyah: An Nadzoriyyah wa At Tathbiiq. (Ammaan: Daarul Masiiroh lin Nasyri wat Tauzii' wat Thibaah, 2007). h, 175 Dalam Muhammad Alfan, Khibroh Ta'limiyah , Ta'allum Al Lughoh Al Arobiyyah ma'a Al La'bi Litarqiyati Daafiiyyah At Tholabah fi Marhalah Al Jami'ah. PINBA IX \& Muktamar IMLA. Al Lughoh Al Arobiyyah Asaas Ats Tsaqofah Al Insaniyyah. 27- 29 Agustus 2015. Jilid I. h, 348.

7 Fathul Mujib dan Nailur Rahmawati. Metode Permainan-permainan Edukatif dalam Belajar Bahasa Arab. (Jogjakarta: Diva Press, 2013). h, 34. 
Silfiyah Rohmawati: Penerapan Hasil Modifikasi Permainan Monopoli Sebagai Media Pembelajaran Berbicara Bahasa Arab

Salah satu media permainan yang bisa dimanfaatkan dalam pembelajaran, baik pembelajaran bahasa atau lainnya adalah permainan monopoli. Seorang pendidik dapat memodifikasi konten atau cara permainan dalam permainan monopoli tersebut.

Monopoli merupakan salah satu permainan papan yang paling terkenal di dunia. Tujuan permainan ini adalah untuk menguasai semua petak di atas papan melalui pembelian, penyewaan dan pertukaran properti dalam sistem ekonomi yang disederhanakan. ${ }^{8}$

Permainan monopoi tersebut sering dimanfaatkan pendidik sebagai media pembelajaran baik bahasa maupun non bahasa, dengan cara memodifikasi konten, langkah-langkah permainan, peraturan-peraturan dan lain-lain.

\section{Berbicara dalam Pembelajaran Bahasa Arab}

Komunikasi dapat dilakukan dengan dua cara, yaitu berbicara dan menulis. Namun, dari dua cara tersebut, yang sering digunakan dalam berkomunikasi adalah berbicara. Karena menurut teori bahasanya, berbicara lebih mudah dibandingkan dengan menulis.

Adapun berbicara merupakan kemampuan untuk mengungkapkan secara lisan tentang perasaan manusia serta sikap sosial, politik, ekonomi, dan budaya, baik secara fungsional seperti percakapan, diskusi dan penyampaikan pesan ataupun secara kreatif seperti mengarang cerita dengan pengucapan dan penyampaian yang baik. ${ }^{9}$

Berbicara merupakan salah satu kompetensi dalam pembelajaran bahasa setelah mendengar, dan dua lainnya adalah membaca dan menulis. Menurut Rusydi Ahmad Thu'aimah, Pembelajaran berbicara pada hakikatnya adalah melatih berbicara, yakni siswa mampu mengekspresikan pada situasi-

8 Anis Nuryati Suprapto. 2013. Permainan Monopoli sebagai Media untuk Meningkatkan Minat Belajar Tata Boga di SMA. Jurnal Ilmiah Guru. (1). h, 40.

${ }^{9}$ Ali Ahmad Madkur. Thuruq Tadris Al-Lughoh Al-Arobiyyah. (Amman: Daarul Masiroh Lin Nasyri wa Tauzii' wat Thiba'ah, 2010). h, 151. 
Silfiyah Rohmawati: Penerapan Hasil Modifikasi Permainan Monopoli Sebagai Media Pembelajaran Berbicara Bahasa Arab

situasi yang dia bicarakan. Berbicara merupakan kompetensi yang dipelajari oleh siswa, jika dia yang berbicara dan sekaligus menjadi pendengar. Oleh sebab itu, sebaiknya guru lebih banyak diam dan berbicara untuk mengarahkan. ${ }^{1}$ 0

Berbicara bahasa Arab penting diajarkan di Indonesia sebagai bahasa kedua, sebab banyak manfaat yang diperoh peserta didik jika menguasainya. Diantara manfaat tersebut adalah untuk komunikasi hubungan diplomasi, untuk bisa mengikuti ajang konferensi Internasional, bahkan juga kepentingan mendapat beasiswa di Arab dan lain sebagainya.

Kendati berbicara merupakan komunikasi yang sering digunakan, namun dalam prakteknya, berbicara bahasa arab dalam pembelajarannya menemukan beberapa kendala, sebagaimana contoh peserta didik merasa malu dalam berbicara bahasa Arab karena khawatir salah. Dengan demikian pendidik harus memberikan stimulus yang bisa menjadikan peserta didik semangat dan memiliki motivasi yang besar dalam berbicara bahasa Arab dengan lancer dan baik.

\section{METODE PENELITIAN}

Penelitian ini merupakan penelitian kualitatif, sebab peneliti melakukan penelitian ini secara alamiah dan natural. Adapun jenis penelitian ini merupakan penelitian diskriptif, dimana peneliti mendiskripsikan tentang modifikasi permainan monopoli serta proses dan langkah-langkahnya dalam pembelajaran berbicara bahasa Arab.

Adapun Teknik pengumpulan data yang digunakan peneliti yaitu observasi dengan jenis partisipan. Dimana peniliti bergabung dalam proses pembelajaran. Dan juga dokumentasi yang berupa catatan-catatan yang diperoleh peneliti saat melaksanakan penelitian.

1 Rusydi Ahmad Thu'aimah. Al Marji' fi Ta'lim Al Lughoh Al Arobiyyah Lin An Nathiqiin bi Lughootin Ukhro. Jilid II. (Jami'ah Ummul Quro Ma'had Al Lughoh Al Arobiyyah Wahda Buhus wa Al Manahij Silsilah Dirosat fi Ta'lim Al Arobiyah, Tanpa Tahun). h, 487 
Silfiyah Rohmawati: Penerapan Hasil Modifikasi Permainan Monopoli Sebagai Media Pembelajaran Berbicara Bahasa Arab

Untuk menganalisa data yang diperoleh, peneliti menggunakan model Miles and Huberman, yaitu model analisis data yang mengatakan bahwa kegiatan dalam analisis data dilakukan secara interaktif dan berlangsung secara terus menerus sampai sempurna dan data mengalami titik jenuh. ${ }^{1}$

\section{HASIL PENELITIAN}

Sebagaimana penjelasan sebelumnya, bahwa monopoli merupakan salah satu permainan yang sudah popular di kalangan masyarakat. Oleh karena itu, peneliti memanfaatkan kepopuleran tersebut dengan cara memodifikasi permainan monopoli menjadi media pembelajaran berbicara bahasa Arab di kalangan mahasiswa yang belajar bahasa arab di Program Khusus Pengembangan Bahasa Arab (PKPBA) di UIN Maliki Malang.

Desain permainan monopoli yang digunakan oleh peneliti tidak jauh berbeda dengan permainan monopoli pada umumnya. Hanya saja, peneliti merubah konten dari monopoli yang asli dan sedikit merubah peraturan permainannya. Adapun kontens dari modifikasi permainan monopoli yang digunakan penulis adalah sesuai materi yang diajarkan di kelas perkuliahan yang mengacu pada kitab Al-arabiyyah li An-nasyi'in.

Modifikasi permainan monopoli yang diterapkan peneliti dalam pembelajaran kompetensi berbicara terdiri dari beberapa peralatan dan bahan, diantaranya yaitu:

1. Bidak-bidak untuk mewakili pemain. Dalam kotak Monopoli disediakan delapan bidak.

2. Dua buah dadu bersisi enam.

3. Kartu hak milik untuk setiap gambar. Kartu ini diberikan kepada pemain yang membeli gambar. Dan di atas kartu tertera nama gambar, pajak

1 Sugiono. Metode Penelitian, Pendekatan Kuantitatif, Kualitatif dan R\&D. (Bandung: Alfabeta, 2010). h, 337. 
Silfiyah Rohmawati: Penerapan Hasil Modifikasi Permainan Monopoli Sebagai Media Pembelajaran Berbicara Bahasa Arab

(tanpa bintang, satu bintang, dua bintang dan tiga bintang), harga menjual kartu, harga membeli bintang dan harga menjual bintang.

4. Papan permainan dengan petak-petak; ibda' (mulai), 24 gambar yang menjadi tema materi, 4 judul pertanyaan, 4 furash (kesempatan), shadaqah, daurah lughawiyyah (diklat bahasa), dan menyanyi.

5. Uang-uangan monopoli (rupiah).

6. 50 bintang.

7. Kartu furash (kesempatan).

8. Gambar piala, yang diberikan kepada pemain yang berkesempatan berada di petak menjawab pertanyaan dan mampu menjawabnya.

Tema-tema gambar pada modifikasi permainan monopoli yang diterapkan penulis ada 24 yaitu Sarapan (تناول الفطور), bermain sepak bola ( لعب (كرة القدم), thowaf disekitar ka'bah ( طواف حول الكعبة ), membaca di perpustakaan (قراءة في المكتبة), pakaian-pakaian (ملابس), buah-buahan (فواكه), sukarno (سوكرنو), belanja di pasar (تسوق في السوق), pemandangan yang indah (مناظر جميلة), membaca Al-Qur'an (قراءة القرآن), tidur dan bangun (نام واستيقظ), dokter di rumah sakit ( طبيب (في المستشفى), pembelajaran dan belajar di kelas (تعليم وتعلم في الفصل), menyembelih kurban (ذبح الأضحية), volli di pantai (كرة اليد في شاطئ البحر), mobil berjalan di jalan (

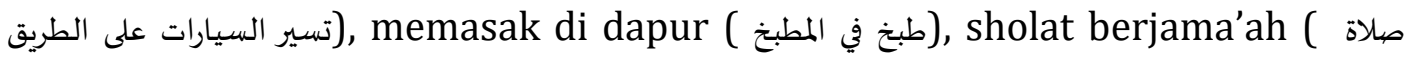
الجماعة), nonton televisi ( مشاهدة التلفاز), maulana malik ibrahim (مولانا مالك إبراهيم), kebun binatang ( حديقة الحيوان), mengerjakan tugas (عمل الواجبات), masjid nabawi ( dan polisi di samping lampu lalu lintas ( (المسجد النبوي (شرطي يقف جانب الإشارة الضوئية).

Dan tema-tema untuk menjawab pertanyaan-pertanyaan ada empat, yaitu perkenalan diri (تعارف), hobi (هواية), cita-cita (همة), liburan yang menyenangkan (إجازة سعيدة). 
Silfiyah Rohmawati: Penerapan Hasil Modifikasi Permainan Monopoli Sebagai Media Pembelajaran Berbicara Bahasa Arab

Selain tema-tema itu, ada materi tambahan yang juga harus dikuasi oleh siswa, yaitu menggunakan dan mengucapkan mata uang rupiah dalam bahasa Arab.

Dari beberapa tema yang telah disebutkan di atas, diharapkan siswa mampu mengungkapkan pikiran, gagasan, perasaan, pengalaman serta informasi melalui kegiatan bercerita dan bertanya jawab tentang materimateri yang telah disebutkan.

Adapun indikatornya adalah melafalkan kosakata dan kalimat dengan pelafalan yang tepat dan benar, menggunakan atau mengucapkan mufrodat dengan tepat dalam berbagai kalimat, bertanya dengan menggunakan kata tanya meliputi; ma, limadza, hal, kam, aina, mata, dan menanggapi atau merespon berbagai pertanyaan dengan tepat.

Berikut ini adalah gambar papan dan kartu hak milik pada modifikasi permainan monopoli yang digunakan oleh peneliti dalam pembelajaran berbicara bahasa Arab:

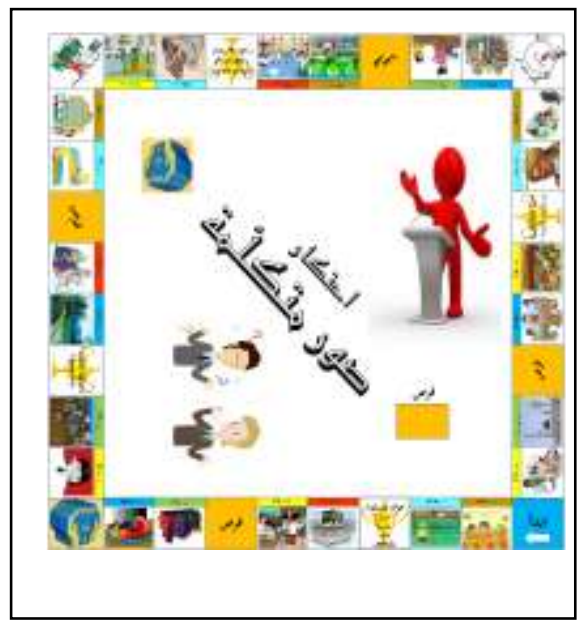

(Papan modifikasi permainan monopoli) 
Silfiyah Rohmawati: Penerapan Hasil Modifikasi Permainan Monopoli Sebagai Media Pembelajaran Berbicara Bahasa Arab

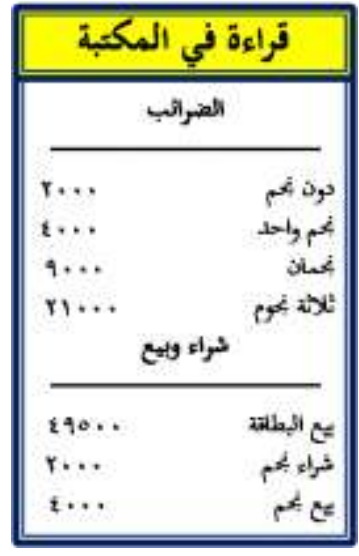

( Kartu hak milik modifikasi permainan monopoli )

Penggunaan media permainan monopoli ini tidak jauh berbeda dengan permainan monopoli pada umumnya. Namun, ada beberapa perbedaan yang harus dijelaskan kepada para mahasiswa supaya tidak terjadi kesalahan dalam bemain.

Sebelum menggunakan media untuk dimainkan, peneliti menjelaskan tentang penyebutan nominal mata uang rupiah mulai dari lima ratus sampai seratus ribu dalam bahasa Arab. Selain itu, peneliti juga memberi bekal bahasa pengantar yang sering diucapkan saat bermain, seperti Saya membeli (أنا أشتري), Saya menjual (أنا أبيع), Saya menukar (أنا أصرّفَ), dan lain-lain. Peneliti juga bisa menyarankan kepada mahasiswa untuk membawa kamus atau mahasiswa juga bisa bertanya kepada dosen tentang kata yang belum diketahui saat permainan sudah dimulai.

Supaya seluruh mahasiswa menjadi aktif, peneliti membagi kelas menjadi lima kelompok. Setiap kelompok terdiri dari lima sampai enam pemain dan satu atau dua pegawai bank yang bertugas mengelolah uang, kartu, bintang dan piala.

Sebelum permainan dimulai, pegawai bank membagikan uang kepada para pemain sebagai modal awal. Setiap pemain mendapat modal uang 
Silfiyah Rohmawati: Penerapan Hasil Modifikasi Permainan Monopoli Sebagai Media Pembelajaran Berbicara Bahasa Arab

sejumlah Seratus delapan puluh delapan ribu lima ratus rupiah, dengan rincian untuk masing-masing nominal uang sebanyak satu.

Adapun Langkah-langkah penggunaan media permainan monopoli adalah sebagaimana berikut:

1. Mahasiswa memulai permainan dari kotak $I b d a^{\prime}$ dengan melempar dadu.

2. Jika mahasiswa sampai pada salah satu kotak monopoli, maka tugasnya adalah;
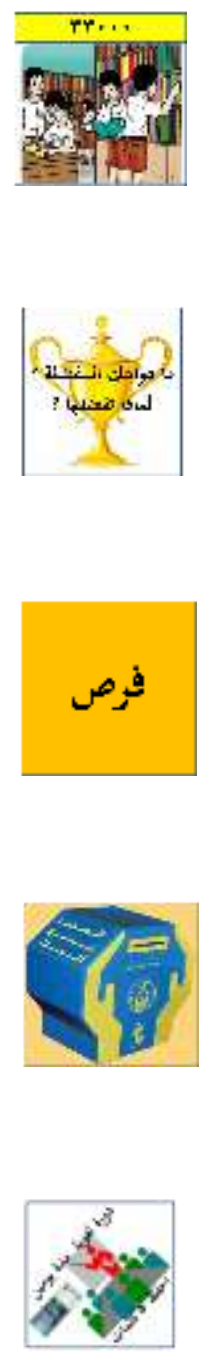

Mahasiswa mendiskripsikan gambar, atau bercerita tentang kegiatan atau kata yang ada di gambar.

Mahasiswa menjawab pertanyaan yang ada di dalam kotak, dan mendapat satu piala setelah menjawabnya.

Mahasiswa mengambil kartu Furash dan membacanya serta mengikuti perintah yang ada di dalam kartu tersebut.

Mahasiswa memberi shadaqah berupa uang, meletakkannya di kotak shadaqah.

Mahasiswa berhenti di kotak ini selama dua putaran untuk menghafalkan 5 mufrodat yang akan disimak oleh pegawai bank, dan setelah itu mendapatkan uang dua puluh ribu. 
Silfiyah Rohmawati: Penerapan Hasil Modifikasi Permainan Monopoli Sebagai Media Pembelajaran Berbicara Bahasa Arab

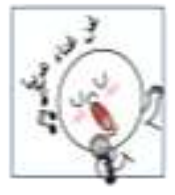
Mahasiswa menyanyikan lagu bahasa arab, dan dia mendapat hadiah uang dari mahasiswa pemain yang lain.

3. Mahasiswa boleh membeli kartu dari kotak gambar yang didiskripsikan, jika belum dibeli yang lain. Adapun harganya sebagaimana tertera di kotak diskripsi gambar.

4. Mahasiswa boleh membelikan bintang pada kotak yang sudah dibeli. Adapun harganya sebagaimana tertera di kartu.

5. Jika mahasiswa berhenti pada kotak yang sudah dimiliki oleh pemain lainnya, maka ia harus mendiskripsikannya dan membayar pajak kepada pemilik kotak. Adapun jumlah pembayaran sebagaimana tertera di dalam kartu, dengan ketentuan kartu saja, satu bintang, dua bintang dan tiga bintang.

6. Jika mahasiswa mengumpulkan dua piala, maka dia berhak mendapat hadiah dari dosen, bisa berupa permen atau lainnya.

7. Adapun pemenangnya adalah mahasiswa yang memperoleh banyak uang setelah dihitung dengan menjumlah uang, harga jual kartu, dan harga jual bintang.

8. Mahasiswa pemenang berhak mendapat hadiah dari guru, supaya menjadi penyemangat untuk diri sendiri dan teman yang lainnya.

\section{SIMPULAN}

Dari penelitian ini dapat disimpulkan bahwa permainan monopoli dapat dimodifikasi dan diterapkan dalam pembelajaran bahasa khususnya dalam penelitian ini yaitu pembelajaran berbicara bahasa Arab. 
Silfiyah Rohmawati: Penerapan Hasil Modifikasi Permainan Monopoli Sebagai Media Pembelajaran Berbicara Bahasa Arab

Ketika memainkan hasil modifikasi permainan monopoli ini, mahasiswa mengungkapkan pikiran, gagasan, perasaan, pengalaman serta informasi melalui kegiatan bercerita dan bertanya jawab tentang materimateri yang telah disebutkan. Adapun langkah-langkah permainan hasil modifikasi permainan monopoli dalam pembelajaran berbicara bahasa Arab ini yaitu sama dengan langkah-langkah permainan monopoli biasanya, hanya saja ada beberapa peraturan yang berubah.

Adapun posisi dosen atau tutor dalam permainan ini adalah sebagai pengarah dan fasilitator, karena mahasiswa yang memiliki peran banyak dalam permainan tersebut, yaitu sebagai banker dan pemai-pemain bidak. Adapun bahasa komunikasi yang digunakan saat bermain adalah bahasa Arab secara total. Apabila ada kosakata yang tidak dikuasai, maka mahasiswa bertanya kepada dosen, sehinga mahasiswa menjadi terbiasa untuk berbicara bahasa Arab.

Diantara rekomendasi-rekomendasi yang disarankan oleh peneliti terkait penelitian ini yaitu sebaiknya tutor atau dosen membacakan peraturan dan langkah-langkah permainan sebelum permainan dimulai, begitu juga tutor atau dosen memberikan pembiasaan atau drill kosakata yang sering digunakan dalam permainan sebelum permainan dimulai.

Adapun rekomendasi secara umum, Hasil modifikasi permainan monopoli dalam penelitian ini bisa diterapkan dalam pembelajaran berbicara bahasa Arab, namun juga bisa digunakan untuk kompetensi bahasa yang lain, seperti mendengar, membaca dan menulis, dan pastinya dengan beberapa peraturan permainan yang berbeda dan bisa disesuaikan. Hasil dari penelitian ini bisa digunakan sebagai bahan modifikasi permainan monopoli yang akan digunakan oleh tutor atau dosen lain dengan menyesuaikan materi dan tingkat kemampuan peserta didik. 
Silfiyah Rohmawati: Penerapan Hasil Modifikasi Permainan Monopoli Sebagai Media Pembelajaran Berbicara Bahasa Arab

\section{DAFTAR PUSTAKA}

Alhilah, Muhammad Mahmud. Al-Al'aab min Ajli Tt tafkir wa At Ta'allum. (Daarul Masiiroh lin Nasyri wat Tauzii' wat Thibaah. Dalam Muhammad Alfan, Khibroh Taklimiyah, Ta'allum Al Lughoh Al Arobiyyah ma'a Al La'bi Litarqiyati daafiiyyah At Tholabah fi Marhalah Al Jami'ah. PINBA IX \& Muktamar IMLA. Al Lughoh Al Arobiyyah Asaas Ats Tsaqofah Al Insaniyyah. 27- 29 Agustus 2015. Jilid I. 2007.

Anis Nuryati Suprapto. Permainan Monopoli sebagai Media untuk Meningkatkan Minat Belajar Tata Boga di SMA. Jurnal Ilmiah Guru. (1). 2013.

Bahagia, suherman. Prinsip-prinsip pengembangan dan Modifikasi cabang olahraga. Jakarta: Departemen pendidikan dan kebudayaan direktorat jenderal pendidikan dasar dan menengah bagian proyek penataran guru SLTP Setara D-III dalam M. Wanda Aginta Bangun. 2018. Pemanfaatan Hasil Modifikasi Pembelajaran Pendidikan Jasmani di SLB-YPAC Cabang Medan. Physical Education, Healt and Recreation. 2 (2). 2000.

Effendy, Ahmad Fuad. Pengajaran Bahasa Arab. Malang: Misykat, 2011.

Ghibari, Tsair Ahmad. Ad Dafi'iyyah: An Nadzoriyyah wa At Tathbiiq. (Ammaan: Daarul Masiiroh lin Nasyri wat Tauzii' wat Thibaah. Dalam Muhammad Alfan, Khibroh Ta'limiyah, Ta'allum Al Lughoh Al Arobiyyah ma'a Al La'bi Litarqiyati daafiiyyah At Tholabah fi Marhalah Al Jami'ah. PINBA IX \& Muktamar IMLA. Al Lughoh Al Arobiyyah Asaas Ats Tsaqofah Al Insaniyyah. 27- 29 Agustus 2015. Jilid I. 2007.

Madkur, Ali Ahmad. Thuruq Tadris Al-Lughoh Al-Arobiyyah. Amman: Daarul Masiroh Lin Nasyri wa Tauzii' wat Thiba'ah, 2010.

Mahmud, Ahmad Fuad. Al-Mahaaraat Al-Lughowiyyah Maahiyatuha Wa Tharaaiqu Tadriisiha. Riyad: Daarul Muslim. 1992. 
Silfiyah Rohmawati: Penerapan Hasil Modifikasi Permainan Monopoli Sebagai Media Pembelajaran Berbicara Bahasa Arab

Mujib, Fathul dan Rahmawati, Nailur. Metode Permainan-permainan Edukatif dalam Belajar Bahasa Arab. Jogjakarta: Diva Press, 2013.

Purwanto, Mustika Sari Ika dan Husna, Hanna Nurul. Implementasi Permainan Monopoli Fisika sebagai Media Pembelajaran dalam Pembelajaran Kooperatif Tipe TGT untuk Meningkatkan Prestasi Belajar dan Mengetahui Profil Kemampuan Berpikir Kritis Siswa SMP. Jurnal Pengajaran Matematika dan Ilmu Pengetahuan Alam. 17 (1). 2012.

Siskawati, Maya, Pargito dan Pujiati. Pengembangan Media Pembelajaran Monopoli untuk Meningkatkan Minat Belajar Geografi Siswa. Jurnal studi sosial. 4 (1). 2016.

Sugiono. Metode Penelitian, Pendekatan Kuantitatif, Kualitatif dan R\&D. Bandung: Alfabeta, 2010.

Thu'aimah, Rusydi Ahmad. Al Marji' fi Ta'lim Al Lughoh Al Arobiyyah Lin An Nathiqiin bi Lughootin Ukhro. Jilid II. Jami'ah Ummul Quro Ma'had Al Lughoh Al Arobiyyah Wahda Buhus wa Al Manahij Silsilah Dirosat fi Ta'lim Al Arobiyah, t.t. 
Silfiyah Rohmawati: Penerapan Hasil Modifikasi Permainan Monopoli Sebagai Media Pembelajaran Berbicara Bahasa Arab 